\title{
Global Economic Crisis and Joblessness in Nigeria's Banking Industry: Agenda for the Future
}

\author{
Eme,Okechukwu Innocent \\ Onyishi,Tony O. Ph.D
}

Department of Public Administration and Local Government, University of Nigeria Nsukka Email: okechukwunncnt@yahoo.com

\section{Doi:10.5901/ajis.2014.v3n4p435}

\section{Abstract}

Axiomatic to posit that the banking sector in Nigeria is yearning for better, skills to reduce distress, and further drive the economy. In recent times, the industry has been bugged by recession, occasioned by mismanagement of funds, inability to adhere to ethical standards, employment of below- average workers, and misplacement of priorities. Many banks have ventured into areas where they lacked the required competence, and, in the process, made traditional, or deposit banking to suffer. One of the major fallouts of this misplacement of priorities is the current pendulum swinging against shareholders as they lose their in vestments, relevance, appeals and contacts to the market. These have occasioned the current job losses in the sector. This article seeks to address the impacts of the economic meltdown on the banking sector and the current job losses triggered by the down turn. The paper concludes by positing that there is a need to redefine the roles banks play in an economy through effective risk management.

Keywords: economic meltdown, recession, bank failure, capitalization, job losses, risk management and banks. Introduction

\section{Introduction}

In 2009, technocrats and business leaders brought together by the Federal government to look into the impacts of the global financial meltdown on the Nigerian economy may have been considering far-reaching measures to contain the impacts of the recession. According to Sam Ohuabunwa, a member of the presidential committee on Economic meltdown told the Broad Street Journal thus:

We never thought the crisis could hit us from the direction of the price of crude oil. We have discovered that we were wrong in saying the impact would not have much impact on Nigeria at the initial state. As a short-term measure, we are considering anything that could lessen the impact of the meltdown on Nigerians (Manuaka, 2009:17).

Now, whereas the government may have taken a step in this direction by announcing a reduction in the pump price of petrol, the global crisis appears to be entering a more critical stage with massive job losses across the globe. As at about February 2009, companies around the world were estimated to have announced about 70,000 job losses. The thinking in some quarters is that several other impact of the meltdown, Nigerian companies are facing the problems of pushing workers into the labour market as a last resort. Although the job cut across in other parts of the world cut across sectors, the financial system and the manufacturing sectors are believed to be Nigeria's vulnerable sectors.

Already, if the projection of the International Labour Organization, ILO, is anything to go by, an estimated 51 million jobs were lost to the crisis in 2009. That will also increase the unemployment rate in the affected countries. While the global unemployment rate is put at six percent by the ILO, that of Nigeria is about 4.9 percent according to the 2007 estimate.

The banks represent an important and useful economic agent in the development matrix. For most of history, the growth, resourcefulness and efficiency of the financial services industry has also been the harbinger of the economic growth and development.

Japan's economic growth had a lot to gain from the growth of its banking industry. Great Britain remains a major economic centre today, partly because of its banking sector. With a strong corporate governance culture, most international financial transactions continue to be routed through London, its financial capital.

Without gainsaying, the banking sector reforms in Nigeria despite its titled emphasis on capitalization, remains the 
most enduring and "successful" of the most administration's economic reforms.

After the consolidation, which tasked the resilience of the personnel and institutions in the banking sector, the confidence with "heavy money" bear, set in. the CBN and the capital market regulators, and the share holders from whom the banks raised their new capital neglected to infuse strong corporate governance framework that would point the way forward to the ethical government of the banks in the fairness to the CBN, it brought out a code of corporate governance, which from recent are observed more in breach. In short, effective corporate governance goes beyond in any codes.

Using the "sick banks" as examples, they are leaders in the good governance business. Their codes are examples in sound business practical; but their business practices, at least in Nigeria are not in sync with the code because governance was just a game their organizational set-up encouraged of ageneses and do not have an elaborate framework to promote good corporate governance practices. In the process, where was big incentive and appetite to doctor the books of the company; hoodwink its shareholders, creditors and regulators, and churn out "rogue financials".

In essence, the CBN, despite its success with the capital raising; will soon find out that their codes, without more would not stem the tide of failure that may be engendered by current developments in the sector.

There has been uneasy calm among bank workers, since the sack of some executives by the Central Bank of Nigeria in August and October 2009. For staff of Union Bank, Oceanic Bank, Afri-bank, Intercontinental Bank, and Fin Bank, this may not be the best time to be a banker.

Their tales may vary, but beneath the calmness is apprehension over their fate and fortunes. For bank's workers, there is uncertainty over job security. There is already apprehension among the workers over their fate should the banks be sold to new investors, as being speculated.

For instance, top management staffs of eight banks were sacked between August 14 and October 3, 2009, for alleged mismanagement of depositors' funds: over 10,000 others have lost their jobs in the last eight months as banks cut cost and bankers hitherto held in high esteem by society; are now treated with scorn. The CBN audit report on the twenty four (24) banks found eight to be in serious financial distress. This development has resulted in the loss of key jobs in many banks. But the fallout of the reforms in the banking industry has forced bankers to reorder their priorities on their career path.

Put differently, the passion for banking profession seems to be declining amidst expectations that certain roles may be phased out soon. The CBN banking reforms have thrown up issues that paint the true picture of what may become of some jobs in the sector in the nearest future. This paper examines the prospects and challenges facing Nigerian banks as majority of them can no longer sustain their huge expenses under the current global economic crisis.

\section{Economic Meltdown}

In a generic sense, a common man's perception of global economic crisis, meltdown or down turn refers to a financial and investment distortion that started at one point (Wall Street, USA) which gradually but steadily affected all financial and investment institutions and economies in the world negatively. Tenuche and Agba (2009) conceived the concept as a recession. A recession is a downturn in a nation's economy. The consequences typically include increased unemployment, decreased consumer and business spending and declining stock prices. Ogunyele (2009) adds that recessions are typically shorter than the periods of economic expansion that they follow, but can be quite severe even if brief. Recovery is slower for some recessions than from others.

Adamu (2007) applied the concept more broadly by positing that it is variety of situations in which some financial institutions or assets suddenly lose a large part of theirs value. Kindleberger and Aliber (2005), Laeven and Valencia (2008) add that in the $19^{\text {th }}$ and early $20^{\text {th }}$ centuries, many financial crises where associated with banking panics, many recessions coincided with these panics. Other situations that are after called financial crisis include stock market crashes and bursting of other financial bubbles, currency crises and sovereign defaults.

The International Monetary Fund (IMF) (2009:1) has noted that the crisis reflects the confluence of several factors:

$>$ As in previous times (of economic recession) the pre- crisis period which was characterized by (I) surging assets prices that proved unsustainable, (ii) a prolonged credit expansion leading to accumulation of debt, (iii) the emergence of new types of financial instruments, and (iv) the inability of regulators to keep up (compare this with Nigeria's current banking crisis).

$>$ There was a new rapid expansion of securitization (not itself a new phenomenon), which changed incentives for lenders and lowered credit standards. Systems became fragile because balance sheets became increasingly complex (further complicated by increased use of off - balance sheet instruments) financial market players were highly leveraged and they relied on wholesale funding and external risk assessments. 
Cross - border spillovers intensified after the crisis broke out because financial institutions and market across borders were closely linked and the risks they bear are highly correlated (IMF, 2009).

The global financial crises also manifested in the following forms:

> Advanced economies are now suffering their worst downturn since the world war (II) occasioning dramatic decline in aggregate demand, leading to extensive destruction of jobs and livelihoods. Credit freeze which has led to virtual halt in lending for investment and consumption; the sharp drop in spending by businesses and households that led to massive layoffs which have further exacerbated the crisis and a myriad of other socioeconomic ripple effects too numerous to list here.

$>$ Productivity and economic growth rate has also fallen in china, brazil, India and other emerging market economies which have been dragged down from 6 percent in 2008 to about $31 / 4$ percent in 2009. This has been mainly due to falling export demands, subdued capital inflows, and lower commodity prices. Correspondingly, growth in all emerging market and developing economies, including sub- Saharan Africa slowed down to $3^{1 / 3}$ percent in 2008 (IMF, 2009:2).

The current global economic meltdown is characteristically contagious in view of the inextricable interlacing character of international economic relations. This is basically why the fiscal and monetary escapades of the world are leading financial and capital and market exhibit roughly similar patterns. A critical study and tracking of the crisis throws up the futility of untamed predatory capitalism which modus operandi rests on making a tiny minority of the population overly rich while the teeming majority are deprived of the basic necessities of life. Onigbogi (2009:2) predicted that the whole world will be affected by the global economic meltdown "and all individual will be called upon to carry part of the cost of this debacle". Indeed it has been predicted that this crisis carries with it the seeds that will lead to the total collapse of the international financial system.

For our purpose global economic crisis refers to the complex interaction of macro economic mismanagement, in complete financial regulation, and defective corporate governance that is affecting different economies across the globe since 2007.

\section{The Nature of the Banking Industry before the Meltdown.}

It is axiomatic to posit. That the recent development in the Nigerian banking industry has revealed that capitalization may not be the real problem facing the industry. This thinking is not new. The same feeling infested the minds of bank regulators about six decades ago (Nwankwo, 1980: Ituwe, 1983 and Ojo and Adewumni (1982). Multiple bank failures then here thought to be a problem that could be run over with rising capital stock. The then British colonial Administration responded by enacting the Banking Ordinance Act of 1962 which required indigenes banks and expatriate banks to capitalize with a minimum of $£ 25,0000$ and 200,000 respectively.

Unfortunately, this regulation did not stop bank failures within the first six years of its operation. The Banking Ordinance of 1958 recapitalization to 400,000 for foreign banks. Shortly after independence in 1960, Nigerian banks Started creating valuable market environment invertors to sustain the economy.

In the present dispensation, the central bank of Nigeria (CBN) had conceived the N25 billion benchmark for the banks, attempting to reposition them to compete favorably with theirs foreign counterparts ( Solnow, 2004). Little was done to address the domestic front and create the significant markets. For the banks (Agbaje, 2009). Suddenly, the unexpected happened. Fire bands have been found flout regulatory guidelines. They have had their top management sacked.

Different banking statutes in the country have stated clearly the duties, powers and responsibilities of the boards of Nigerian banks. Section 40 of the 1991 Banks and Other Financial Institutions Act (BOFIA), for instance, spells out the dos and don'ts of the top management of banks, particularly, as they affect credit management. This provision repeats section 35 of the 1969 Banking Decree (to which BOFIA serves as repeal).

Such persons are prohibited from seeking gift, commission, service, gratuity, money, property of anything of value from customers for:

(a) procuring a loan, an advance or credit;

(b) discounting any draft, note, cheque, bill of exchange or other obligation; and

(c) Permitting over - withdrawal without the bank's consent Section 43) (i)).

Ekpo (2007) captured these corporate governance attributed when he described the subject as the manner in which the power of a company is exercised in running the company's portfolio of assets and resources ( $\mathbf{p} \mathbf{x})$. Akpakpan (2007) corroborated him, viewing corporate governance as "the manner in which company boards carry out their duties" 
$(p v)$; this manner explained as "the processes, structures and relationships through which the board of directors oversees what its executives do" (Dayton, 1982 in Akpakpan, 2007, p v).

Alo (2006) pushed the discussion forward by emphasizing accountability for shareholders' value on the part of the directors as an attribute of corporate governance. It is such accountability that makes section 46 of BOFIA, 1991 to warn members of the board of a bank to always take the right steps to manage the affairs, particularly, credits, of their bank. Failure to do this is a criminal offence which renders the offending executive (s) punishable.

In (2006) the CBN came up with further documentation of a code of good corporate governance for Nigerian banks. This code, according to the bank, become necessary because of financial scandals noticed around the world, the bank cited the following weaknesses as common features of corporate governance in Nigerian banks:

- ineffective board oversight functions;

- fraudulent and self-serving practices among members of the board, management and staff;

- overbearing influence of the chairman or other officers especially in family- controlled banks;

- weak internal controls;

- passive shareholders;

- Poor risk management practices resulting in large quantum of non-performing credits including insider-related credits; and

- Technical incompetence, poor leadership and administrative weakness.

It was based on these features that the CBN in that year gave the banks the following principles of good corporate governance:

- Installation of a committed and focused Board of Directors.

- A proactive and committed management team.

- Well defined and acceptable division of responsibilities among various cadres within the structure of the bank.

- Definite management succession plan.

- Culture of compliance with rules and regulations (CBN. 2006).

\section{Recent Development}

On august 9,2009 , the $C B N$, in a swift move, made one of the biggest exercises of its regulatory powers in recent times when it sacked top management staff of five banks (Union, Intercontinental, Oceanic, Afribank and Finbank).

It is clear that they do not have the ability to meet their obligations to depositors and creditors, as they are in grave situation ..... their management have acted in a manner detrimental to the interest of their depositors and creditors (CBN, 2009, p.1)

What gave the CBN the enhancement to take this action was excessive credit risk taken by these banks which characteristically resulted in a large amount of non-performing loans. This, according to the apex bank, was a sign of poor corporate governance and lax credit administration. Statistics given to buttress its action include the fact that the five banks jointly posted the following features.

- Percentage of non-performing loans to total loans ranged from $19 \%$ to $48 \%$ which called for extra provision of N 539-09 for bad and doubtful loans in five banks.

- Aggregate non-performing loans stood at N 1.1 trillion or $40.8 \%$ of industry total.

- Margin loans alone amounted to N 456.2 billion.

- Exposure to oil and gas was staggering N 487 billion.

- Combined applications to the inter- bank market for credit support were the largest amounting to $89.81 \%$ of total for the industry.

- Liquidity ratios ranged between $17.65 \%$ and $24 \%$ as against the $25 \%$ minimum specified.

- Percentage share of total loans was $39.9 \%$ (indicating a huge) share of the banking

- Percentage share of total deposit of $29.99 \%$ (market - a share) that should not be allowed to be swept under.

- Percentage share of total assets of $31.47 \%$ (all these as at May 31, 2008).

In response, the CBN not only made available N 400 billion bails -out credit line to the banks but had to replace their chief executive officers and executive directors. Sundry debtors of the banks were ordered to pay back their loans. Reacting, some of the banks and their debtors have contested the CBN figures. Perhaps a more revealing issue is the plea by some of the debtors for understanding, citing the harsh economic environment as the reason for their inability to pay up. 


\section{Financial Distress and Uncertainty of Banking Jobs in Nigeria: Background and Development.}

It is axiomatic to posit that signs of financial distress crept into the Nigerian banking sector in October 2008 when some banks saddled with heavy capital and loan losses, became permanent customers of the Expanded Discount Window (EDW). When Sanusi Lamido Sanusi became the Governor of Central Bank of Nigeria. (CBN) in June 2009, he shocked Nigerians, starting with the fact that five banks were in big trouble. The executive management of the banks were subsequently sacked and replaced with fresh teams for the next two years. Following the release of another CBN examination result on October 2, the apex bank again welded the big stick; as it sacked the managing and executive directors of more three. The table below identifies some of the chairmen and directors of banks that have been disengaged based on the number of years they have served in their positions.

Table I: Chairmen and Directors of Banks that have been Removed Based on Tenure Question

\begin{tabular}{|c|l|c|c|c|}
\hline S/N & \multicolumn{1}{|c|}{ Director } & Bank & Position Held & Appointment Date \\
\hline 1 & Oba Otudeko & First Bank of Nigeria & Chairman & 1997 \\
\hline 2 & Garba Duba & First Bank of Nigeria & Director & 1990 s \\
\hline 3 & Oye Hassan - Odukale & First Bank of Nigeria & Director & 1990 s \\
\hline 4 & Ferdinand Ngogo Alabrabra & UBA & Chairman & 1990 s \\
\hline 5 & Willy Kroegor & UBA & Director & - \\
\hline 6 & Samson Sankey & Citi Bank & Chairman & 1985 \\
\hline 7 & Raymond Obieri & Intercontinental Bank & Chairman & 1989 \\
\hline 8 & Chuks Alabi & Intercontinental Bank & Director & 1989 \\
\hline 9 & Hyacinth Enuwa & Intercontinental Bank & Director & 1989 \\
\hline 10 & Samuel Adegbite & Intercontinental Bank & Director & \\
\hline 11 & Macanlay Pepple & Intercontinental Bank & Director & 1990 s \\
\hline 12 & Gilbert Chikeln & Zenith & Director & 1996 \\
\hline 13 & Victor Osibodn & GT Bank & Director & 1990 \\
\hline 14 & Ahmed Jada & GT Bank & Director & 1990 \\
\hline 15 & Tokunbo Adesanya & GT Bank & Director & 1990 \\
\hline 16 & Isiaku Umar & Intercontinental Bank & Director & 1989 \\
\hline
\end{tabular}

Source: Aminu, A. (2010:4) Term Limit: Otudeko, Alabraba to Step Down from bank Boards", This Day, Saturday, April 3.

Following the hammering of these Chief executives and executive directors, customers have become weary of these banks, although there has not been a run on them, as initially anticipated. Since the end of the CBN audit exercise, the banks have under cost rationalization agenda. One of this cost rationalization agenda is the current sacking gale in Nigerian banks.

The sacking gale in Nigeria banks continued, just before the year 2009 wound down on Thursday (1 ${ }^{\text {st }}$ January, 2010), with the management of Union Bank of Nigeria (UBN) announcing the sack of 77 workers and recruiting 150 with effect from January 4, 2010.

The recruitment, the bank said in a statement by its spokesman, Francis Barde, is part of efforts to reinvigorate its workforce. The newly-employed include about 70 of the bank's "current temporary/outsourced staff, and were selected after rigorous recruitment procedures and will undergo five weeks induction programme at different locations across the country including Lagos, Kaduna and Owerri, to prepare them for the challenges of banking and to integrate them into the bank's culture of professionalism and best ethical practices." (Durojaiye, 2010:23)

The recruitment of fresh staff, the bank added, will be a continuous exercise as part of efforts to reposition Union Bank and ensure that its esteemed customers gain from improved service delivery as well as customer-focused processes.

The 77, the statement continued, were disengaged following decision on outstanding disciplinary cases, while 46 staff was sanctioned for various acts of misdemeanor. A total of 19 others, however, got letters of commendation for job excellence.

The bank had earlier employed 500 fresh graduates as part of the efforts to regenerate its human capital, while the management has re-assured customers and other stakeholders of its commitment towards the positive and progressive transformation of the bank to maximize the opportunities presented in the industry.

Union Bank PIc on December 18, 2009 sent unusual gifts to 1,500 members of its staff: "Letters of disengagement" from the bank. The sack letters were served to the affected staff around 3p.m. on the faithful day, changing the atmosphere in the financial institution's banking hall throughout the country to that of shock and disbelief. Those affected 
were from the position of manager to executive banker level.

The bank is said to have about 5,000 workers nationwide. Investigation revealed that in the banks' over 300 branches nationwide, five workers from each branch had their appointment terminated. Sources said they would be paid three-month basic salaries irrespective of the number of years they have served the bank.

The sack, which came just two days after their salaries were paid, had been hanging in the air after the new management of the bank alleged leakage of sensitive information about a transaction by the new Managing Director of the bank Mr. Lai Mahmud Alabi, who allegedly granted a waiver of N31 billion to some influential Nigerians, an amount higher than the capital base of the bank going by the 2005 consolidation exercise that pegged the capital base of every Nigerian bank at N25 billion. (Durojaiye, 2010:23)

The bank had earlier laid off senior officers from the positions of Generation Manager (GM), Assistant General Manager (AGM) and Deputy General Manager (DGM) up to senior managers.

A competent source said the new management had requested from each branch manager to submit the name of at least five members of staff in their respective departments "whom they could not work with" for the sack.

"At least three of the managers I know reused to comply because the directive did not follow any due process and was likely leading due process and was likely leading to witch-hunting," a source said. "Two of those three did not survive the on slaughter."

It was also learnt that some managers who complied were not spared in the exercise. Similarly, Oceanic Bank International PIc, which declared a loss of N286 billion, had also disengaged 250 members of staff out of the 1,400 penciled in for sack in its rationalization exercise.

Wema Bank Plc had sacked about 500 workers, including 25 top managers in September, 2009 while Spring Bank Plc also reportedly laid off about 200 members of staff. The mass sack in Oceanic, which was implemented after the bank's management meeting, affected workers across departments, branches and regions of the bank.

Oceanic said in the disengagement letter to the affected staff that the exercise was in furtherance of the decision of management to return the organization to profitability. The letter reads in part; "Subject to the terms of this letter, you are to proceed on voluntary separation with immediate effect. Your condition of employment continues to apply up till the separation date." (Durojaiye, 2010:23)

Seven banks including Bank PHB, Spring Bank and Afribank are said to have compiled a list of workers to be eased out, in an exercise that is expected to send over 6,000 bankers back to the labour market.

A source that attended Oceanic Bank's management meeting, which preceded the retrenchment, said:

The action was taking to cut overhead, so that the bank can return to productivity. According to the source: An appraisal of every staff was done to ensure the exercise was transparent, adding: Those that are leaving might have been affected due to underperformance or redundancy (Durojaiye, 2010:23).

The mass sack in the banks is coming on the heels of the downturn in the banking industry, as amply manifested in the results of the CBN/NDIC (Nigeria Deposit Insurance Corporation) joint examinations of the banks published on August 14 and October 2, 2009.

After making huge provisions and incurring net losses nearing N2 trillion, the banks under CBN-appointed new management are leading the mass staff lay-off, adducing operations efficiency. Although the former Minister of Labour and Productivity, Adetokunbo Kayode, has condemned the retrenchments, the CBN has insisted it was necessary "as the banks need to shed fat to remain fit". About 6, 268 jobs have been lost since the beginning of the banking sector reforms with more on the queue. Table two below highlights the number of job losses since late 2009.

Table II: Some Sacked Workers by Banks

\begin{tabular}{|c|c|}
\hline Banks & Number of Affected Staff \\
\hline Oceanic & 2,000 \\
\hline Intercontinental Bank & 1,346 \\
\hline First bank & 485 \\
\hline Stanbic IBTC & 300 \\
\hline Zenith & 600 \\
\hline Union Bank & 137 \\
\hline Finbank & 700 \\
\hline Spring bank & 200 \\
\hline Wema & 500 \\
\hline Grand Total & 6,268 \\
\hline
\end{tabular}

Source: Eze, I and Chiejina, A. (2010:59) "Pondering Fate of Sacked Bank Workers", Business Day Monday 26 April. 


\section{Implications of the Job Losses}

However, the Federal Government said through the then minister of labour and productivity, Adetokumbo Kayode, that it would not allow any action by bank managements that could cause labour crisis in the polity.

The minister in a statement by an Assistant Director in charge of Media in the Ministry; Samuel Olowookere, therefore directed the banks to stop the lay-offs. But the CBN rose in defense of the banks.

The statement reads in part:

The minister warned that the recent report on the mass refreshment in the banking sector would not be tolerated by the government, hence his resolve to meet with the operators in the banking industry including the CBN, which is the regulator of the banking industry (Durojaiye and Ighomwenghian, 2010:24).

But the Deputy Governor of the CBN, Tunde Lemo, said the mass sack sweeping through banks was inevitable. Lemo added that it had been discovered through full disclosure and transparent financial reporting that the growth in the banking sector in the past three years had been superficial. He said:

We have to understand the magnitude of the calamity that has befallen the global financial system. The most hit sector in this global meltdown is the financial sector. And we have discovered of late that the huge capital the banks had been saying they had was fake. If two - third of the capital the banks claimed they raised is not there, then it was bubble capital, which means that the reality on ground, they have to be slim and fit (Durojaiye and Ighomwenghian, 2010:24).

This development has resulted in the loss of key jobs in many banks. The role of risk managers in banks will continue to be given top priority. This may explain why experienced risk managers are in high demand and this role will continue to be strengthened in banks.

Nurudeen Abbey, risk management officer in one of the old generation banks, said the increase in bank fraud has led the management of the 24 banks to pay more attention to risk management structures, including engaging more auditors to look into their books. According to him:

Banks are expected to employ current techniques and risk financing tools that can reduce business risk to the barest minimum. Besides, the implementation of strong and effective risk management and controls within the industry promotes stability. (Nweze, 2010: B1)

Managing Partner of KPN Consulting Stephens Adebayo, who has been involved in recruitment drives for banks for eight years, disclosed that bank auditing will become more like contractual roles because of the increasing needs to guarantee objectivity. This was demonstrated during the CBN/NDIC audit of the 24 banks, which involved world-class auditors from Europe and America working with internal auditors of the banks.

He believes that core banking jobs like marketing is central to the survival of banks. It is the segment that deals with pooling resources together. He went on to posit that:

The marketing role in banks is expected to be boosted as the scramble for market shares intensify. Competition in the industry is based on market perception, service quality and pricing. Banking products in the country are generic although some product differentiation is employed by creating brand names for some deposit products (Nweze, 2010:B1)

But, it will take experienced risk managers and go-getter marketing officers to mobilize deposits and create quality risk assets for banks. Marketing roles in banks will continue to drive the industry. While experienced and high-flyer marketers will keep taking key management positions in banks.

Another banking job to watch is public relations, now called corporate communications in most banks. This job function is likely to shrink in the near future. Already, many banks have contracted key roles of banks' PR executives to external media and public relations companies which monitor and design their images of choice. Press releases from some banks now come from such external consultants and it is expected that, in the future, the PR role will be shared between a few insiders and external media consultants. The in-house communications managers may have to concentrate on managing staff-to-management communications, and internal crisis management systems. Adebayo adds:

The PR jobs will continue in banks but its operational scope will not be expanded. It will attract a limited workforce with management relying on external communication experts to handle major information flow between the banks and customers (Nweze, 2010:B8).

The front desk staff roles, such as receiving cash, cheque and making payments, among others, would be drastically reduced as automated teller machines (ATMs) and e-banking take root in the industry. This will lead to loss of jobs and may also be a cost-saving measure for banks. Banks will, however, continue to increase their need for Ordinary National Diploma (OND) and Higher National Diploma (HND) as a cost-saving measure too.

Likewise, bullion van drivers may have a good portion of their jobs taken over with the introduction of amoured 
bullion vans. This role is gradually being phased out as banks embrace the new bullet proof vans.

A South African integrated cash management firm, SBV Services Limited, owned by the country's four largest banks - Absa, Nedbank, FirstRand and Standard bank - was recruited by the CBN to provide amoured bullion van services for banks and financial houses.

Bullion van drivers, security personnel and other staff that monitor cash movement of banks may be sidelined as banks embrace this new technology. Drivers, cleaners, security personnel and maintenance jobs will still be in high demand but will continue to be contracted out to specialists. This has saved banks huge costs and reduced their staff strength to manageable numbers.

It is also expected that the CBN, led by Sanusi Lamido Sanusi, will continue to have an influence on the appointment of key staff in banks, especially at the executive level. The apex bank was responsible for the appointment of new executive directors and managing directors for the eight troubled banks - Intercontinental Bank, Afribank, Oceanic Bank, Bank PHB, Fin Bank, Equatorial Trust Bank, Union Bank and Spring Bank.

The CBN influence over employment criteria will continue to grow, especially with the new guidelines insisting that intending bankers be screened by the police. The oversight role of the CBN is now structured to include banking and other financial institutions supervision.

Although banking in Nigeria is still evolving, analysts insist on the urgent need for banks to provide adequate training for their staff to secure a workforce with required skills to meet emerging challenges. Today's banker needs to bring to his work a higher level of job-related knowledge.

Managing Director of Aeris Agency Services, a recruitment company based in Lagos, Mark Eduk, said Nigeria as an emerging market also has an emerging approach to its banking services. According to him:

Our banking sector is evolving. What has happened in the sector in the last 10 years is a blueprint. The banking sector is doing what it is supposed to be doing, which is self-regulation, and the industry will reap the benefits in due course (Nweze, 2009: B8)

A female staff in one of the old generation banks affected by the CBN reforms disclosed that the bank has laid off over 1000 staff in the last three months, and that more staff will be affected. "Job security in this industry is weak and it may not improve for a long time to come," (Nweze, 2009:B8) she said.

The General Secretary, National Association of Banks Insurance and Financial Institutions (NUBIFIE), Segun Ola, told The Nation that both senior and junior staff cadre in many banks, including those not affected by the CBN/NDIC Audit report, have been thrown into the labour market in recent months. He disclosed that there are few of the banks that have worked out severance package for their staff, but many others simply send the staff packing without any cushion or getting NUBIFIE involved. With the banks still grappling with severe economic crisis for giving out bad loans, it is expected that more retrenchment will persist. Ola however, insisted that any termination of employment must be in line with the existing Labour laws in the country and must cut across all the cadres.

Acting National President, Association of Senior Staff of Banks, Insurance and Financial Institutions (ASSBIFI), Salako Olusoji, aggress with Oni that many senior and junior staff of banks has been losing their jobs in recent months. According to Olusoji: "Accepted that the jobs have been lost, but the redundancy benefits contained in our Collective Agreement and other terminal accruals still need to be paid to the affected staff"(Nweze, 2009: B8)

Lead consultant, Ekini Consult \& Associates, Olu Oyeniran told The Nation that the current CBN reforms will lead to more job losses, as the banks will be forced to come down to earth. More ethical and realistic operations will ultimately require fewer hands than currently engaged. According to him:

The only areas I see expansion is risk management and monitoring/supervision because of the rapid and massive expansion of operations post-consolidation. Everywhere to go in Nigeria, you see the evidence of this in the number of new branches but it has become clearer to stakeholders that commensurate growth in the number of qualified personnel has not been recorded (Nweze, 2009:B8)

Olu Oyeniran, who has been training many youth on how to secure valued jobs, said individuals affected or downsized in the course of the CBN reforms can change the direction of their carrier completely, depending on their interests and talents. It may be necessary for them to take afresh look at their carrier/experience with a view to reconfiguring their CVs or out-rightly start their own businesses.

Obviously, many bankers were attracted from various sectors of the economy to the industry because of monetary gains. One should expect that once these attractions were no more; there will be another round of 'rearrangement' of labour configuration. 


\section{Recommendations}

In other for the financial institutional to check the drift, the underlisted recommendations are suggested.

1. Banks should embark on cost saving measures to make them stay afloat. Such cost saving measures to be considered include considering shutting down some of their branches to cut cost.

2. Banks should strive to capture more of the retail market through robust product development, up grade of risk management process and the attainment of operational efficiency through elimination of non-essential costs.

3. Banks should also embark on cost optimization by verifying and dealing with non-performing/idle assets with a view to sustaining viable ones. This will ensure the right - sizing of the workforce to fit revenue generating capacity, streamline branch expansion, eliminate poorly performing subsidiaries and investment in technology and project management methodologies and to introduce process automation in operations.

The CBN should dispose certain assets that may be surplus to requirement - private jets, boats, yachts and other property - thereby enhancing the banks' liquidity

4. Banks, Unions, Stakeholders, and the CBN should explore common ground to halt the retrenchment of workers without the banks paying workers' severance benefits and

5. The banks' management should implement an across - the - board salary cut that will further streamline its cost profile and further enhance their drive for operational efficiency.

\section{Conclusion}

The emerging events following the crisis in the banking sector from the day Sansui took over has brought to the fore the greed of some of the management in the industry. Barring last minute hitches, the bankers' Union, under the aegis of the National Union of the Banks, Insurance and Financial Institutions Employees (NUBIFIE) and other affiliate unions like the Association of senior staff of Banks, Insurance and Financial Institutions in Nigeria (ASSBIFI) among others, have hinted of plans disrupt activities in some of the banks to protest the arbitrary sacking of their members, among other demands are not addressed.

Some of today's troubles were sown by the responses or lack of them to the financial crisis of the late 1990s. CBN failed to address risks building in the Nigerian economy. Regulators and supervisors of financial institutions were no longer grounded in reality. Financial innovation and competition vastly expanded services and shunted aside from the realities of psychology, organizational behaviour systemic risks and the complexities of market and humans.

From this assessment of the financial situation in Nigeria, there is going to be more job losses in the banking industry. The working class is now jittery over the bank's estimation of job cuts this year.

\section{References}

Adesina, J. O. (2003) "Adjustment and the Transformation of Labour Identity: What's new and Does it Matter? In Attahiru, Jega (editor) Identity Transformation and Identity Politics Under Structural Adjustment in Nigeria. Kano: The Centre for Research and Documentation.

Agbaje, O. (2009) "reflections on Nigerian Banking (5)". Business day. Wednesday, August 26,p. 60.

Ahiazu, A. I. "Crucial Influences on Rule Making Methods: A Note for Effective Management of Industrial Relations in Local Governments", in Tayo,F. (Ed) Collective Bargaining in the public sector in Nigeria. Lagos: Macmillan.

Akpala, A. (1982) Industrial Relations Models for Developing Countries: The Nigerian System, Enugu: fourth Dimension.

Akpakpan, E. B. ( 2007). "Introduction". Proceedings of a Workshop on Corporate Governance: Issues, Process, and the Law. Uyo: Akwa Ibom Investment and Industrial Promotion Council (AKIIPOC), August, PP. v-viii.

Alo, o. (2006). "Promoting Good Corporate Governance in the Insurance Industry". In Issue in Recapitalization and Consolidation in the Nigerian Insurance Industry. Editor: Chiejina, E. O. Lagos: Nigeria Insurance Association (NIA), PP. 93 - 105.

Appleby, R. C (1982) Modern Business Administration (3rd ed) London: Pitman Books Ltd

Basu, H (2005), Public Administration; Concept and Practices, New Delhi; Princeton-Hall.

Bean, R. (1996) Comparative Industrial Relations: An Introduction to Cross-National perspectives. $2^{\text {nd }}$ ed. London: International Thompson Business Press.

Clegg, H. (1976). The System of Industrial Relations in Great Britain, Oxford: Basic Black well.

Clegg, H.A (1979) The Changing Systems of Industrial Relations in Great Britain Oxford: Basic Blackwell.

Cordova, E. (1980), "Collective Labour Relations in Latin America: A Reappraisal". Labour and Society, Vol. 5. No.3, July.

Damachi and Tayo Fashoyin (eds) Contemporary Problems in Nigeria Industrial Relations, Lagos: Development Press Ltd.

Damachi, U.G. and Fashoyin, T (1988) "Industrial Relations for Africa Economic Recovery" Nigerian Journal of Industrial Relations, Vol.2 December, 47-58. 
Doeringer, P.B(1981) "Industrial Relations Research in International Perspective", in P.B Doeringer (ed) Industrial Relations in International Perspective: Essay of Research and Policy, London: Macmillan.

Dunlop, J.T. (1958) Industrial Relations Systems, New York: Holt.

Durojaiye, R and Ighomwenghian, K (2010) "When Banks Live above Means", Sunday Independent, January 3, Pp. 23-24 and 27

Ejiofor, P. N and Anagolu, V (eds) (1984) Managing the Nigerian Workers; Ibadan: Longman.

Ejiofor, P. (1986) Foundations of Business Administration, Onitsha: Africa-FEP Pub Ltd.

Eme, O.I (995) "Military and Democratization in Nigeria: A Case study of June 12 Elections" Unpublished B.SC Project Department of Political Science University of Nigeria, Nsukka.

(1998) "The Politics of Federalism in Nigeria: A Case study of Revenue Allocation (1946-1996) Unpublished M.Sc. Thesis Department of Public Administration and Local Government Studies, University of Nigeria, Nsukka.

(1999) "Industrial Relations in a Dysfunctional Federal Structure: A Case of Nigeria Lessons for the Future "Unpublished Young Managers Competition Organized by Lagos Zone.

Eme, O. I. and Ugwu, S. C (2009) "Trade Union Reforms in Nigeria: Implications of Trade Union Amendment Act of 2005 on Industrial Relations, Work and Productivity." A Paper Presented at the National Conference on "Work and Productivity in the Era of Globalization: The Nigerian Experience" held at Usman Danfodio University, Sokoto in February 24th and 27th.

Eme, O. I. and Okeke, M. I. (2009) "Employee Welfare, Incentives and Benefits in Nigeria: An Assessment of the Implications of Minimum Wage on Work and Productivity. A Paper Presented at the National Conference on "Work and Productivity in the Era of Globalization: The Nigerian Experience" held at Usman Danfodio University, Sokoto in February 24th and 27th.

Fashoyin, T. (1980) Industrial Relations in Nigeria. Lagos: Longman.

Federation of Nigeria (The Trade Union (Amendment) Act 2005) Abuja: Government Printers.

Goodman, J.F.B et al "Rules in Industrial Relations Theory: A Discussion, Industrial Relations Journal vol.6.

Hyman, R. (1975) Industrial Relations: A Marxists Introduction, London: Macmillan.

Matanmi, S (1993): "Labour under IBB" In Godwin A.S Ogboghodo (Ed) Seven Years of IBB. Vol. 3 Lagos: Daily Times Pub.

Mervin-Gumeded, W. (2004) "Fight for Survival" BBC Focus on Africa, October-December.

Mills, D. (1986) Labour-Management Relations, London Macmillan.

(1979) "Third World Strikes in Perspective", Development and Change 10:321-337.

Nigeria Labour Congress (n.d) Study Guide to the NLC Draft Policy Document for NLC Zonal Conference.

Nweze, C (2009) "Uncertainty Clouds Banking Jobs" The Nation, December, 7 Pp. B1 \& B8

Obasi, I.N (1997) "Introduction to Industrial Relations" Unpublished Mimeo.

Odunfa, S. (2004) "When Friends Fall Out" BBC Focus on Africa, October-December.

Okene, O.V.C. (2006) "Curbing state interference in Worker's Freedom of Association in Nigeria". Journal of Not-for-Profit Law Vol.8, No.4 August, 86-95.

Olaoye - Osikolu, (2010) "Go Million More Jobs to go this Year - World Bank", The Nation, Monday, January 18, pp B1 and B8.

Onyeonoru, I. (2003) "Trade Unions and New Liberal Reforms: Globalize Trends and Emergent patterns of Contestation". Text of paper prepared for SABA congress, Durban, $2^{\text {th }}$ June-2nd July, 2003, on "Resistance, reconstruction and Democracy in Post-Colonial Africa.

Otobo, D. (1981) "The Nigerian General Strike of 1981", Review of African Political Economy, No. 22.

Otobo, D. (1995) The Trades Union Movement in Nigeria. Lagos: Malthouse Press Ltd.

Schillinger, H.R. (2005) "Trade Unions in Africa: Weak but Feared", Occasional Papers: International Development Cooperation, BonnGermany.

Schregle, J. (1982) Negotiating Development: Labour Relations in Southern Asia, Geneva: ILO.

Seers, L.C. (1981) Introduction to Organizational Behaviour, Santa Monica: Goodyear.

Ubeku, A.K. (1983) Industrial Relations in Developing Countries: The Case of Nigeria. London, Macmillan.

Ujo, A. A (20010, Understanding Public Administration, Kaduna: Anyaotu Pub.

Walker, K.F. (1974) "Workers" Participation in Management: Problems; Practices", Geneva: ILO Bulletin.

Webb, S. \& Webb, B. (1902). Industrial Democracy. (2nd ed.) Longmans: Green and Co.

Yesufu, T.M. (1984). The Dynamics of Industrial Relations: The Nigerian Experience. Ibadan: University Press Ltd.

Yoder et al., (1958) Handbook of Personnel Management and Labour Relations, New York: McGraw-hill Books Ltd.

Yusufu, T. M (1984): The Dynamics of Industrial Relations: The Nigerian Experience; Ibadan: University of Ibadan Press.

Yusuf, I.A. (2010) "Banks, Unions, Management, Square Up", The Nation on Sunday, January 1, pp 41 - 43. 